\title{
The Effect of Demographic Variables Upon University Students' Service- Learning Experiences in Marketing
}

\author{
Susan D. Geringer*, Alan C. Canton, Andreas W. Stratemeyer and William Rice
}

Craig School of Business, California State University, Fresno, Fresno, CA 93740-8001, USA

\begin{abstract}
Purpose of the Study: The components of a successful service-learning (SL) program are Intended Outcomes, Program Environment and Student Characteristics. Much has been written about the first two factors, but little empirical research is available concerning Student Characteristics or SL in marketing courses. The study examines the impact of various demographic characteristics on student outcomes.

Method/Design and Sample: A questionnaire was developed utilizing items from a survey instrument designed for assessing the impact of service-learning by the Center for Academic Excellence at Portland State University [1]. Data were gathered from thirty-eight sections of a marketing course over a period of eight years, resulting in 2,135 usable student surveys.

Results: The findings indicate that academic major, age and ethnicity had a strong impact upon student SL experiences in marketing. Gender had only a minor impact on these student outcomes. The results indicate that some adjustments, with respect to program or project design, may be needed for certain students.

Value to Marketing Educators: Faculty considering the implementation of SL assignments in their courses should be made aware that student diversity does indeed make an impact on the SL experience in marketing. This information would allow faculty to offer their students the very finest service-learning experience available.
\end{abstract}

Keywords: Service-learning, marketing, education, assessment outcomes, demographics.

\section{INTRODUCTION}

Service-learning is an academically rigorous, learnercentered experiential format of education that combines meeting community needs with purposeful educational growth for the student through the use of classroom materials and real-life organizational experience [2-4]. Experiential learning may also be an effective approach for faculty to develop a better understanding in students of culture, global marketing and marketing ethics [5]. The need for individual understanding of various ways of looking at the world may well be increased through the students' participation in service-learning assignments [6]. Servicelearning also helps in teaching students a variety of helpful skills: Team-building, enhanced social and cultural consciousness, increased intellectual curiosity, problem solving, time management, etc. $[7,8]$.

Although a plethora of information has been written about SL in non-business courses, fewer studies have focused on SL in business courses. Specifically, little empirical research is available concerning SL in marketing courses. However, one study provides a framework for the inclusion of service-learning and the specific application of service-learning projects in marketing courses [9]. Within the conclusions, itstates "the next step for research in

*Address correspondence to this author at the Craig School of Business, California State University, Fresno, Fresno, CA 93740-8001, USA; Tel: 559-278-5121; Fax: 559-278-8577; E-mail: sgeringer@csufresno.edu service-learning in the marketing curriculum should focus on empirical studies" [9]. However, the number of empirical studies dealing with business students is limited, and the number dealing with marketing students is even more limited. Only one study indicates that business majors were part of the sample [10].

\section{A MODEL FOR SERVICE-LEARNING}

A framework for designing or assessing SL might utilize the scheme as conceptualized and illustrated in Fig. (1) [11]. As indicated in the framework, measurement of the Actual Learning Outcomes of service-learning in a specific course or discipline is a function of the interaction of three factors: Intended Learning Outcomes, Educational Environment and Student Characteristics. Therefore, the success of a servicelearning program is based on the interaction of these three factors [11]. Although much has been written about Intended Outcomes and Program Environment, much less has been written about Student Characteristics.

\section{Intended Learning Outcomes}

SL can address a number of different possible outcomes [12]. Therefore, it is important for the faculty to select specific desired outcomes to be achieved through the SL activity. The students participating in the current study were enrolled in a Marketing Concepts course in which the faculty has determined the specific desired outcomes to be Civic Responsibility, Career Development, Academic and Personal Development. These Intended Learning Outcomes were 
developed by the participating faculty, based upon previous SL research $[1,9,13]$.

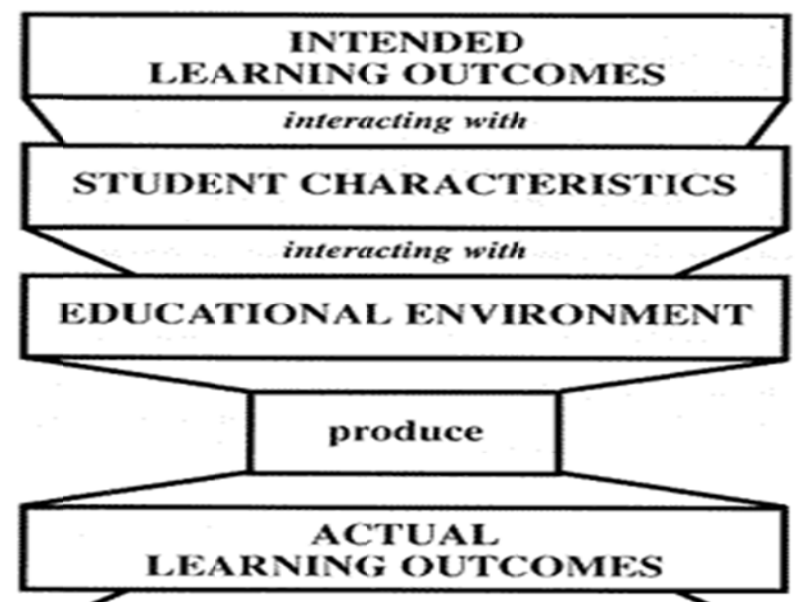

Fig. (1). Service-learning model.

\section{Education Environment}

Educational Environment relates to those factors that enhance the impact of the SL activity (e.g. quality placements, connection with course content and reflective activities). In the current study, the faculty was provided with as much information as possible in order to ensure that the environment for the SL projects was similar, regardless of the instructor $[13,14]$. In addition, all faculty involved in this study were trained in SL and mentored by their colleagues. This is an important aspect of creating a sound study, based a correlation between the amount of faculty SL training and student perceptions [15]. This study indicated that SL had an optimum impact on students who had teachers who were trained and followed sound practices in SL.

\section{Student Characteristics}

A third factor that can impact the ability to achieve learning objectives is individual Student Characteristics. This can include such factors as grade point average, attitudes toward service, or level of cognitive development [16]. Learning outcomes may also be a function of demographics, such as age, gender, ethnicity and student academic major.

\section{Actual Learning Outcomes}

All three of these factors must be considered when designing a service-learning activity or program. While much research has been done on most of these factors, there are few studies available on the impact of student demographics on actual learning outcomes nor on diversity in SL [17]. Although an extensive bibliography of research was developed that addresses the impact of SL through 2000 , the only research articles included in this bibliography concerned student demographics in relation to SL $[13,18]$. The authors also concluded that further empirical studies were necessary because not enough information existed to be able to develop an accurate profile of those students who would more readily engage in community service projects.

Results of a study which examined student involvement in SL activities based upon age, gender, classification, academic major and outside employment, indicated that students strongly supported the concept of SL [19]. In regard to the demographics of ethnicity and gender [20]. One study determined that there was no significant difference between men and women in their attitudes and behavior toward community involvement. Another study addressed the impact of age, gender, race and major area of study in relation to the Community Service Attitudes Scale (CSAS) and found that men scored higher in one area of the CSAS, whilst women scored higher in all the other CSAS areas [21].

Numerous studies have examined men and women in relation to their community service capacity $[10,21]$. Another study found that females were more likely than males to support service assignments in their university classroom settings [18]. It was also found by one author that women participating in community service displayed a higher level of empathy than men who participated [22]. In regard to future participation of students in further community service, it was also determined that gender played a significant role in future participation, citing that women were much stronger in this capacity [22, 23]. The literature is highly supportive of the view that gender plays a role in service learning participation and attitude of the participants. However, one study found that gender did not matter when students were asked their perceptions of participation in community service [24].

Research has also addressed the issue of age in relation to SL and community service. One effort studied members of university sororities and fraternities and found a significant difference in age and the volunteerism of the participants [25]. Specifically, the authors indicated that younger Greek members were more likely to participate in volunteer activities than their older counterparts. One researcher's study is quite specific in finding that individuals under the age of 24 are most likely to volunteer in comparison to other ages [26]. Thus, these authors insinuate that age affects the participation level of those participating in volunteerism, and younger students will have a stronger likelihood of participating than their older peers.

Research studies have also indicated that ethnicity plays a role in individuals' community involvement. Numerous studieslooked specifically at ethnicity and community involvement [27]. Another study found that Caucasians scored higher on their attitudes about estimates of future community involvement than African-Americans [20]. In a study of urban-based higher education institutions, it was found that African-American students were more service oriented in their attitudes than Euro-Americans or AsianAmericans [28]. In regard to ethnicity and volunteerism, Caucasian members of university Greek organizations were most likely to participate in volunteerism, followed by African-Americans, Hispanics, Asians and those who identified themselves as others [25]. A second study's findings echo this information [29]. It found that Caucasians participated in volunteerism at a higher rate thanAfricanAmericans. However, two other individual studies indicated that no significant differences were identified when addressing ethnicity and levels of volunteerism [30, 31].

The demographic of a student's major area of study has also been analyzed in relation to volunteerism and SL in 
previous research studies. One study found the single variable which significantly related to choosing a student's service option was academic major, with social science students being more likely to choose service-learning than students within other majors [32]. Another study found that academic major had a significant impact uponservicelearning performance [33]. Another found that students' favorability toward participating in service-learning activities was directly related to their academic major while a third echoed these sentiments in their findings that differences occurred in their subjects' levels of volunteerism based upon the students' majors [31, 32]. However, several studies found no relationship between a student's academic major and their civic attitude [34, 35]

Based on the research efforts discussed, this empirical study was designed to test the impact of student diversity on the service-learning experience in marketing. The specific null hypotheses that were tested are:

$\mathrm{H}_{1-4}$ : Students' gender $\left(\mathrm{H}_{1}\right)$, age $\left(\mathrm{H}_{2}\right)$, ethnic background $\left(\mathrm{H}_{3}\right)$, and academic major $\left(\mathrm{H}_{4}\right)$ will have no effect upon their service-learning experiences in marketing.

\section{STUDY DESIGN}

The study was comprised of undergraduate business majors enrolled in an upper-division Marketing Concepts course at a university located in the western United States. Prior to participating in this study, the students included in the sample had recently completed a class-assigned mandatory service-learning project, which required a minimum of fifteen hours service in a nonprofit organization. All students were given the same survey (APPENDIX A), which was completed during a regular class period upon completion of the SL project.

The questionnaire was developed utilizing items from a survey instrument designed for assessing the impact of service-learning by the Center for Academic Excellence at Portland State University [1]. Some modifications were made in order to incorporate questions relevant to this specific course and assignment [16]. Twenty-one items measured one of four different Intended Learning Outcomes: (1) Career Related Outcomes; (2) Academic Outcomes; (3) Personal Development Outcomes; and (4) Civic Responsibility Outcomes. Students were asked to identify the extent to which they agreed or disagreed with each statement on a five-point Likert scale $(1=$ strongly disagree and 5=strongly agree). In addition, four demographic questions assessing gender, age, ethnicity, and academic major were included. Table $\mathbf{1}$ presents the demographic characteristics of the sample.

To minimize the impact of using multiple instructors with varying experience using SL, data were gathered from thirty-eight sections of the marketing course over a period of eight years (2003-2010), representing 2,310 student participants. The elimination of respondents due to missing data resulted in 2,135 usable surveys. In addition, the faculty was provided with information, training and mentoring in service-learning in order to provide an Educational Environment that was consistent. Table $\mathbf{2}$ presents the abbreviated item topic along with its associated outcome objective, as well as the mean, standard deviation and itemto-total correlations for each item and the Cronbach alpha for each of the four scales. Although two items were weak in the reliability analysis, they were retained for further analysis in order to keep the original scales intact.

Table 1. Student Sample Characteristics

\begin{tabular}{|c|c|c|}
\hline Demographics & Frequency & Percentage \\
\hline \multicolumn{3}{|l|}{ Gender: } \\
\hline Male & 1,080 & 50.6 \\
\hline Female & 1,055 & 49.4 \\
\hline \multicolumn{3}{|l|}{ Age Group: } \\
\hline Under 21 & 687 & 32.2 \\
\hline $21-25$ & 1,189 & 55.7 \\
\hline $26-30$ & 147 & 6.9 \\
\hline $31-35$ & 51 & 2.4 \\
\hline Over 35 & 61 & 2.9 \\
\hline \multicolumn{3}{|l|}{ Ethnic Group: } \\
\hline Caucasian/White & 959 & 44.9 \\
\hline African American & 421 & 19.7 \\
\hline Asian/Asian American & 249 & 11.7 \\
\hline Hispanic & 352 & 16.5 \\
\hline Other & 154 & 7.2 \\
\hline \multicolumn{3}{|l|}{ Academic Major: } \\
\hline Management & 563 & 26.4 \\
\hline Marketing & 737 & 34.5 \\
\hline Information Systems & 127 & 5.9 \\
\hline Accounting & 267 & 12.5 \\
\hline Finance & 222 & 10.4 \\
\hline Other & 219 & 10.3 \\
\hline
\end{tabular}

Note: Overall $\mathrm{n}=2,13$.

\section{RESULTS}

This study is designed to test the impact of student diversity on the service-learning experience in marketing. In order to reduce the data, an R-type factor analysis was applied to a correlation matrix of the 21 variables in order to identify latent dimensions. The Kaiser-Meyer-Olkin measure of sampling adequacy indicated that factor analysis was appropriate (index value $=.968$ ). The Bartlett test of sphericity also revealed that the correlation matrix has significant correlations among some of the variables (chisquare $=36,229.02, d . f$. $=210, p<.000)$. Principle components analysis with a Varimax rotation was used, and the latent root criterion indicated that four dimensions had eigen values greater than one and explained $68.7 \%$ of the total variance. These four dimensions related to Career Related Outcomes, Academic Outcomes, Personal Development Outcomes, and Civic Responsibility Outcomes. Table $\mathbf{3}$ presents comparisons for the demographic variables of gender, age, ethnic background, and academic major across each of these four learning outcomes using ANOVA. Significant differences between group means were further analyzed using Scheffe post hoc tests where appropriate. 
Table 2. Mean Results and Reliability Analysis of Service-Learning Items

\begin{tabular}{|c|c|c|c|c|c|c|}
\hline Item & Question Topic $^{\mathrm{a}}$ & Objective $^{\text {b }}$ & $M$ & $S D$ & Item-Total Correlations & Scale Alpha \\
\hline 1 & Made me more aware of possible career opportunities. & $\mathrm{C}$ & 2.9 & 1.3 & .74 & \multirow{3}{*}{.87} \\
\hline 2 & Made me more aware of benefits of volunteering. & $\mathrm{C}$ & 2.8 & 1.3 & .81 & \\
\hline 3 & Made me more marketable upon graduation. & $\mathrm{C}$ & 2.8 & 1.3 & .73 & \\
\hline 4 & Better understanding of course content. & A & 3.0 & 1.3 & .81 & \multirow{6}{*}{.92} \\
\hline 5 & Should be used in more business classes. & A & 3.0 & 1.2 & .65 & \\
\hline 6 & Enhanced my leadership skills. & A & 3.0 & 1.1 & .78 & \\
\hline 7 & Enhanced my ability to communicate my ideas. & A & 2.9 & 1.2 & .81 & \\
\hline 8 & Showed me how marketing is used in every day life. & A & 2.9 & 1.3 & .83 & \\
\hline 9 & Learned more than using a traditional project. & A & 2.8 & 1.4 & .80 & \\
\hline 10 & Expanded my understanding of people in general. & $\mathrm{P}$ & 2.8 & 1.2 & .76 & \multirow{6}{*}{.91} \\
\hline 11 & Enabled me to learn more about diversity. & $\mathrm{P}$ & 2.8 & 1.1 & .80 & \\
\hline 12 & Helped me define my strengths and weaknesses. & $\mathrm{P}$ & 2.9 & 1.1 & .78 & \\
\hline 13 & Was comfortable working with other cultures. & $\mathrm{P}$ & 2.9 & 1.2 & .81 & \\
\hline 14 & Helped me become aware of personal biases. & $\mathrm{P}$ & 3.0 & 1.1 & 62 & \\
\hline 15 & Had a positive effect on my self-esteem. & $\mathrm{P}$ & 2.8 & 1.2 & .74 & \\
\hline 16 & Showed me how I can become more involved. & $\mathrm{R}$ & 2.7 & 1.4 & .69 & \multirow{6}{*}{.82} \\
\hline 17 & Was already volunteering. & $\mathrm{R}$ & 3.1 & 1.4 & .23 & \\
\hline 18 & Made me more aware of needs in my community. & $\mathrm{R}$ & 2.8 & 1.3 & .71 & \\
\hline 19 & Intend to continue volunteering at same agency. & $\mathrm{R}$ & 3.0 & 1.2 & .44 & \\
\hline 20 & Felt I made a contribution to the organization. & $\mathrm{R}$ & 2.8 & 1.4 & .72 & \\
\hline 21 & Will probably continue to volunteer. & $\mathrm{R}$ & 2.8 & 1.3 & .76 & \\
\hline
\end{tabular}

${ }^{a}$ Five-point Likert scale, where $1=$ Strongly Disagree, $5=$ Strongly Agree.

${ }^{\mathrm{b}} \mathrm{C}=$ Career Related outcomes, $\mathrm{A}=$ Academic outcomes, $\mathrm{P}=$ PersonalDevelopment outcomes, $\mathrm{R}=$ Civic Responsibility outcomes.

\section{Gender}

Overall, there were no significant differences between males and females across all four learning outcomes. Interestingly, every item except for one (item 14) received a higher rating from the male respondents than from their female counterparts. Although male respondents were somewhat more enthusiastic about the service learning outcomes, the evidence against the first hypothesis is rather weak at best. As a result, Hypothesis 1 is accepted since the SL attitude items had no significant differences, suggesting that students' service-learning experiences in marketing were rather similar across gender.

\section{Age}

There were significant differences between the age categories across all four learning outcomes, although mean and median ages were not examined. Scheffe post hoc tests suggest that the predominant differences reside between the under-21 age category and the 26-30 age categories, respectively. The under-21 group had the lowest means while the 26-30 group had the highest means for most of the service-learning items. Consequently, the 26-30 age group exhibited the greatest enthusiasm for the benefits of the SL project and its associated outcomes. Based on these results, the evidence against the second hypothesis is very strong. Overall, seventeen items exhibited significant mean

Table 3. ANOVA for Demographic Variables Across Learning Outcomes

\begin{tabular}{|c|c|c|c|c|}
\hline Outcome & Gender $F$ & $\underset{F}{\text { Age }}$ & $\begin{array}{c}\text { Ethnic } \\
\text { Background } \\
F\end{array}$ & $\begin{array}{c}\text { Academic } \\
\text { Major } \\
F\end{array}$ \\
\hline Academic Outcomes & .73 & $16.08^{*}$ & $24.64 *$ & $10.93^{*}$ \\
\hline Personal Development Outcomes & .15 & $16.13 *$ & $27.68 *$ & $13.28 *$ \\
\hline
\end{tabular}


differences between the various age categories. As a result, Hypothesis 2 is rejected because most of the students' service-learning experiences in marketing were not similar across age.

\section{Ethnic Background}

There were significant differences between the ethnic categories across all four learning outcomes. Scheffe post hoc tests revealed that African Americans were significantly different than every other ethnic group. For nineteen servicelearning items that had significant mean differences across ethnic backgrounds, African Americans had the lowest mean attitudes on every item. Hispanics, by and large, had the highest mean attitudes regarding the benefits of the SL assignment and its corresponding learningoutcomes. Specifically, they had the highest mean attitudes on twelve of the SL items. These results suggest that the evidence against the third hypothesis is also very strong. In all, nineteen attitude items had significant mean differences between the various ethnic backgrounds, resulting in the rejection of Hypothesis 3. Therefore, most of the students' SL experiences in marketing were not similar across ethnic background.

\section{Academic Major}

There were significant differences between the ethnic majors across all four learning outcomes. According to Scheffe post hoc tests, marketing majors differ significantly from management majors on fifteen attitude items and from accounting and finance majors on seventeen attitude items, respectively. Altogether, marketing majors did not differ significantly from information systems majors. However marketing majors had the lowest mean on nineteen of the items. Accounting majors, on the other hand, had the highest mean attitudes on seventeen of the SL items and had the greatest enthusiasm for the potential benefits of the SL assignment and its associated outcomes. Hypothesis 4 is rejected since most of the students' service-learning experiences in marketing were not similar across academic major.

\section{DISCUSSION}

The findings indicated that certain demographic characteristics, including academic major, age and ethnicity, did have a strong effect upon SL experiences in marketing. The only demographic variable to have a marginal impact on student outcomes was gender. Although males tended to have higher mean attitudes than females across all the service-learning items, these differences were not statistically significant.

The data indicate a possible immaturity on the part of the under-21 group concerning their overall experiences with the service-learning project. Perhaps their youth explains their lack of enthusiasm regarding the potential benefits of the SL assignment with regards to their learning outcomes. The older students, particularly the 26-30 age category, are more aware of the needs of the nonprofit organizations in the community and are more willing to give up their time to help these organizations.

The differences in mean attitudes across ethnic backgrounds may be a product of the fact that some students, particularly Hispanics, were allowed the opportunity to work with individuals at the nonprofit agencies that are from a background different than their own, thus affording them the opportunity to expand their awareness of others, as well as their own feelings of others. Perhaps these findings also indicate that other students, such as African Americans, were unclear as to how they may become involved with aiding nonprofit organizations, and the SL assignments did not allow them the opportunity to participate in a fulfilling experience that they wish to continue in the future.

Marketing majors indicated a highly significant difference in their SL experience for all learning outcomes. Unfortunately, their mean attitudes for almost all servicelearning items were lower than the other academic majors. This is particularly ironic given the fact that the SL assignments, in the marketing courses in which these students participated, required mandatory SL assignments which addressed marketing issues, and marketing majors should have been more highly attuned to the learning opportunities that these projects provided. Accounting majors, on the other hand, seemed better able to understand these opportunities as evidenced by their high mean attitudes across the learning outcomes.

\section{RECOMMENDATIONS}

Although one comment suggests that the motivating of faculty to make changes in their curriculum is one of the loftiest challenges facing marketing education today at the undergraduate level, this study recommends that demographic information gleaned may be useful in such changes [36].

After completing this study, specific recommendations for future studies are as follows:

1. The continuation of empirical studies to determine methods faculty may use to offer students valuable service-learning experiences within the study of marketing.

2. Studies that indicate why older students, male students, accounting majors and Hispanic students are more favorable toward the service learning experience in marketing.

3. Studies in business-related fields, other than marketing, which investigate the impact of student diversity on the service-learning experience.

4. Studies that indicate how younger, female, African American, marketing majors may undergo a more fulfilling experience from the service-learning assignment.

Upon examination of the related literature and this study, faculty considering the implementation of SL assignments in their courses should be made aware that student diversity does indeed make an impact on the SL experience in marketing. Although much literature has been devoted to the fact that SL may be a valuable and worthwhile experience for students, there is a definite need for future empirical studies that address the accomplishments and implications of these assignments. This information would allow faculty to offer their students the very finest service-learning experience available. 


\section{CONFLICT OF INTEREST}

The authors confirm that this article content has no conflict of interest.

\section{ACKNOWLEDGEMENTS}

Declared none.

\section{APPENDIX A}

\section{Service-Learning Student Survey - Marketing 100}

The purpose of the following survey is to obtain your thoughts regarding the service-learning assignment you completed for this course. There are no right or wrong answers. Answer each question based on your own experience. The information will be treated as confidential and has no bearing on the grade you receive for this assignment. Use the back of this page for any written comments you wish to make about the assignment. Respond to each statement on the Scantron using the following scale:

$1=$ Strongly Disagree $2=$ Disagree $3=$ Neutral $4=$ Agree 5

$=$ Strongly Agree

The service-learning assignment:

\section{(Career Related Outcomes)}

1. Made me more aware of possible career opportunities in the nonprofit sector.

2. Made me more aware of how volunteering can benefit my career or the business where I work.

3. Will make me more marketable when I graduate.

\section{(Academic Outcomes)}

4. Helped me to better understand the concepts of marketing.

5. Should be used in more classes at our business school.

6. Enhanced my leadership skills.

7. Enhanced my ability to communicate my ideas in a real world context.

8. Helped me to see how marketing can be used in everyday life.

9. Was a better way for me to learn about marketing than completing a traditional research project.

\section{(Personal Development Outcomes)}

10. Expanded my understanding of people, in general.

11. Enabled me to learn more about diversity.

12. Helped me to define some of my personal strengths and weaknesses.

13. Helped me to become comfortable working with cultures/social groups other than my own.

14. Helped me to become more aware of my own biases and prejudices.

15. Had a positive effect on my self esteem.

\section{(Civic Responsibility Outcomes)}

16. Showed me how I can become more involved in my community.

17. I was already volunteering in my community before taking this course.

18. This assignment helped me become more aware of the needs in my community.

19. I intend to continue performing service at the agency I worked at for this assignment.

20. I feel that the work I did made a contribution to the organization I served.

21. I probably will continue to volunteer somewhere in the community after this course.

\section{REFERENCES}

[1] Driscoll A, Gelmon SB, Holland BA, et al. Assessing the impact of service-learning: a workshop of strategies and methods. Portland, OR: Portland State University Center for Academic Excellence 1998.

[2] Kenworthy-U'Ren AL, Peterson TO. Service-learning and management education: introducing the 'we can approach.' Acad Manag Learn Educ 2005; 4(3): 272-7.

[3] McIntyre FS, Webb DJ, Hite R. Service learning in the marketing curriculum: faculty views and participation. Market Educ Rev 2005; 15(1): 35-45.

[4] Petkus Jr E. European study tour application of experiential learning processes in marketing education. College Teaching Methods and Styles Journal. Retrieved 2008 March 26, from:http://64.233.179.104/scholar?hl=en \&lr=\&q=cache

[5] Ferrell L, Buchanan MA. Torch awards for marketplace ethics: providing students 'hands on' experience with marketing ethics. Market Educ Rev 2006; 16(1): 47-51.

[6] Chonko LB. Business school education: some thoughts and recommendations. Market Educ Rev 1993; 3: 1-9.

[7] Schmidt SL, Richter A. Course formats for teaching management consulting. J Educ Bus 2006; 82(1): 56-62.

[8] Schwartz J, Fontenot RJ. Recreating the principles of marketing group project: a case study in service learning. J Adv Market Educ 2007; 11: 11-8

[9] Petkus E. A theoretical and practical framework for servicelearning in marketing: Kolb's experiential learning cycle. J Market Educ 2000; 22(1): 64-70.

[10] Stukas AA, Snyder M, Clary EG. The effects of 'mandatory volunteerism' on intentions to volunteer. Psychol Sci 1999; 10(1): 59-64.

[11] Gainen J, Locatelli P. Assessment for the new curriculum: a guide for professional accounting programs. Accounting Education Series, 11, Sarasota, Florida: Accounting Education Change Curriculum Commission and American Accounting Association 1995.

[12] Eyler J, Giles WE, Stenson CM, Gray CJ. At a glance: what we know about the effects of service-learning on college students, faculty, institutions and communities, 1993-2000, $3^{\text {rd }}$ ed. [Retrieved: 2012 April 3]. Available from: http://www.compact.org/reso urce.aag.pdf

[13] Rama DV, Ravenscroft SP, Wolcott SK, Zlotkowski E. Servicelearning outcomes: guidelines for educators and researchers. Issues Account Educ 2000; 15(4): 657-93.

[14] Sherwood C, Nordstrom R. Service-learning in marketing education - integrating classrooms and communities: the challenge. Proceedings of the Western Marketing Educators, Ohio; USA 2000.

[15] Tannenbaum SC, Berrett RD. Relevance of service-learning in college courses. Retrieved 2011 June 13 from: http://www.highbe am.com.

[16] Sherwood C. Assessing the impact of service-learning in a principles of marketing course: some empirical results. Proceedings of the Marketing Educators' Conference, 106-111. 
[17] O'Grady C. Integrating Service Learning and Multicultural Education: An Overview. Mahwah, New Jersey: Laurence Erlborem and Associates Publishing 2006.

[18] Berthiaume J. L.Community service learning perceptions of selected students attending a university in the southeast region of the United States. Unpublished doctoral dissertation, University of Southern Mississippi 1999.

[19] Blackwell AP. Students' perceptions of service learning participation in the college of Health and Human Services at the University of Southern Mississippi. Unpublished doctoral dissertation, University of Southern Mississippi 1996..

[20] Eklund-Leen S. J.Astudy of the relationship of student cocurricular activity, intensity of involvement and other variables to attitude and estimated behavior toward community involvement among college students. Unpublished doctoral dissertation, Kent State University 1994.

[21] Chapman JG, Morley R. Collegiate service learning: motives underlying volunteerism and satisfaction with volunteer service. J Prevent Intervent Commun 1999; 18(1/2): 19-33.

[22] Loewen DE. Reflection on the service experience of first year college students: A cohort analysis. An unpublished doctoral dissertation. University of Iowa 1998.

[23] Wymer W. Sensation seekers and civic participation: Exploring the influence of sensation seeking and gender on intention to lead and volunteer. Int J Nonprof Volunt Sec Market 2008;13(4): 287-300.

[24] Siebold ML. (An assessment of a community service program for allied health students. An unpublished dissertation. University of Sarasota 1998

[25] Foster-Bey J, Dietz N, Grimm, R. College students helping America. Corporation for national and community service. Retrieved 2012 February 22 from: http://www.nationalservice.org/ pdf/06_0503_mentoring_report.pdf.

[26] Lough, B. J. (2010) International volunteerism in the United States, 2008. Washington University in St. Louis Research Brief, Center for Social Development Publication No. 10-11.
[27] Mattis JS, Jagers RJ, Hatcha CA, Lawhon GD, Murphy EJ, Murray YF. Religiosity, volunteerism and community involvement among African-American men: An exploratory analysis. J Commun Psychol 2000; 28(4): 391-406.

[28] Smedick WD. A study of the effect of a volunteer service program at an urban based institution of higher education on the current level of service achieved by alumni had participated in the program. An unpublished dissertation. Morgan State University 1996.

[29] Wilson J, Musick M. Who cares? Toward an integrated theory of volunteer work. Am Sociol Rev 1997;62: 694-713.

[30] Marks H, Jones S. Community service in the transition: Shifts and continuities in participation from high school to college. $\mathrm{J}$ of Higher Educ 2004;75: 307-339.

[31] Cruce TM, Moore JV III. First-year students' plans to volunteer: An examination of the predictors of females more likely to volunteer. Proceedings, Annual Form for the Association for Institutional Research 2006.

[32] Ender M, Martin L, Cotter D, Kowalewski BM, Defiore J. Given an opportunity to reach out: heterogeneous participation in optional service-learning projects. Teach Sociol 2000, 28(3): 206-19.

[33] Rocha CJ. Evaluating experiential teaching methods in a policy practice course: The case for service learning to increase political participation. J Soc Work Educ 2000; 36(1): 23-37.

[34] Papadakis K, Griffin T, Frater J. Understanding volunteers' motivations. Proceedings of the Recreation Research Symposium, New York; USA, 2014.

[35] Seider SC, Gillmor SC, Rabinowicz SF. The impact of community service learning upon the world views of business majors versus non-business majors at an American university, J Bus Ethics 2010; 98(3): 485-503.

[36] Lamont LM, Friedman K. Meeting the challenges of undergraduate marketing education. J Market Educ 1997; 19: 17-31. 